THE ROOTS OF UKRAINIAN NATIONALISM: GALICIA AS UKRAINE'S PIEDMONT 
Other books by Paul Robert Magocsi

Let 's Speak Rusyn—Bisidujme po-rus 'ky (1976)

The Shaping of a National Identity (1978)

Let's Speak Rusyn-Hovorim po-rus ' $k \bar{y}$ (1979)

The Rusyn-Ukrainians of Czechoslovakia (1983)

Galicia: A Historical and Bibliographical Guide (1983)

Our People $(1984,1994)$

Ukraine: A Historical Atlas (1985)

Carpatho-Rusyn Studies, 2 vols. (1988-98)

The Russian Americans (1989, 1996)

The Carpatho-Rusyn Americans $(1989,2000)$

The Rusyns of Slovakia (1993)

Historical Atlas of East-Central Europe $(1993,2002)$

A History of Ukraine (1996)

Let's Speak Rusyn and English-Besheduime po angliiski i po ruski (1997)

Of the Making of Nationalities There Is No End, 2 vols. (1999)

The Roots of Ukrainian Nationalism (2002)

Books edited by Paul Robert Magocsi

The Ukrainian Experience in the United States (1979)

Wooden Churches in the Carpathians (1982)

Morality and Reality: Andrei Sheptyts 'kyi (1989)

Persistence of Regional Cultures (1993)

A New Slavic Language Is Born (1996)

Encyclopedia of Canada's Peoples (1999)

Canada's Aboriginal Peoples (2002)

Encyclopedia of Rusyn History and Culture (2002) 


\section{THE ROOTS OF UKRAINIAN NATIONALISM}

Galicia as Ukraine's Piedmont

PAUL ROBERT MAGOCSI

UNIVERSITY OF TORONTO PRESS Toronto London Buffalo 


\section{www.utppublishing.com}

(C) University of Toronto Press Incorporated 2002

Toronto Buffalo London

Printed in Canada

ISBN 0-8020-4738-6

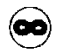

Printed on acid-free paper

National Library of Canada Cataloguing in Publication Data

Magocsi, Paul R.

The roots of Ukrainian nationalism: Galicia

as Ukraine's Piedmont

Includes bibliographical references

ISBN 0-8020-4738-6

1. Galicia (Poland and Ukraine) - History - Autonomy and independence movements. 2. Ukrainians-Galicia (Poland and Ukraine) - History. 3. Nationalism - Ukraine History. I. Title

DK608.9.G35M33 $2002 \quad 947.7^{\prime} 9 \quad$ C2001-901230-6

University of Toronto Press acknowledges the financial assistance to its publishing program of the Canada Council for the Arts and the Ontario Arts Council.

University of Toronto Press acknowledges the financial assistance to its publishing program of the Government of Canada through the Book Publishing Industry Development Program (BPIDP). 